\title{
Die Algemene Sinode van die Nederduitse Gereformeerde Kerk van 1990 en die Gelofte van 1838
}

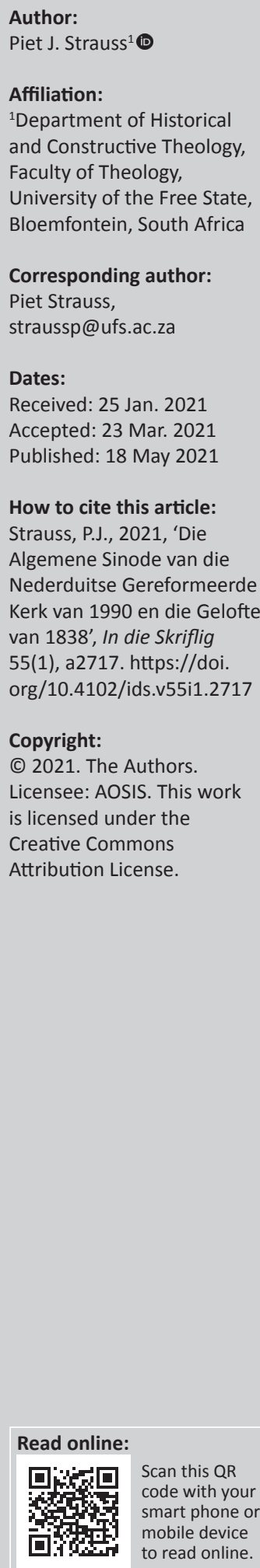

\begin{abstract}
The General Synod of the Dutch Reformed Church of 1990 and the Covenant of 1838. The Dutch Reformed Church as a church consisting of mainly Afrikaners, was confronted by a new societal dispensation and a new government in South Africa in and after 1994. The trend of the new constitution of 1996, as well as a new public discourse laid the emphasis on the individual and his rights in a society open to all. This discourse implicitly communicated negative tones on actions, activating minority groups for their own separate ideas. As if the General Synod expected this coming challenge, the Synod of 1990 already had a report of its Commission on Doctrine and Actual Affairs on the Dutch Reformed Church, keeping the Day of the Covenant of the Voortrekkers in 1838. This article investigated the stance of this General Synod on this issue with two, seemingly main objectives: an acceptable, grounded reason for people to keep the Day of the Covenant, and a positive link between the Covenant of 1838 and reconciliation in a modern South Africa. The method used was a study of literature and primary sources on these issues. The General Synod of 1990 made two relevant statements in its new environment. In the first place, it decided that individuals should associate with the Covenant on moral grounds and not because they are forced to do so. The core of the Covenant of 1838 was the request that God enable people taking the vow, to win the battle foreseen - the Battle of Blood River - and to promote Christian values for establishing a new Christian society. An issue which is still relevant in South Africa today. That is why the Voortrekkers promised to build a church as the focus point of their forseen society. The second statement of this Synod was that reconciliation as a catchword in the 1990s in Christian South Africa, is part of the promotion of a Christian society. Reconciliation in a biblical perspective remains relevant in South Africa.
\end{abstract}

Contribution: Seen from the approach of this article as a Christian approach, these statements of the General Synod of 1990 help the Dutch Reformed Church as church to fulfil its tasks in Soutern Africa today.

Keywords: support; covenant; culture; race; sabbatical; commemorating; honour God; covenant; morally; spiritual character.

\section{Aktualiteit en inleiding}

In die aandskemer van apartheid Suid-Afrika beveel die Algemene Sinode van 1986 van die Nederduitse Gereformeerde Kerk (NGK) by NG gemeentes aan dat elke gemeente voorsiening moet maak 'vir sy lidmate om 'n erediens tydens geloftefeesviering by te woon'. Terselfdertyd toon die Sinode 'n aanvoeling dat die komende nuwe bedeling in Suid-Afrika - 'n nuwe staatkundige bedeling wat in 1994 tot 'n 'nuwe Suid-Afrika' lei - nuwe vrae aan die NGK oor Geloftedag, soos dit tot 1994 op die staatsbepaalde kalender van die Republiek aangedui is, stel. Daarvoor moet dié Sinode, wat deur die stuk 'Kerk en Samelewing - 1986' apartheid soos dit in praktyk gefunksioneer het, veroordeel het, óók gereed wees. Daarom gee hierdie Sinode aan sy Kommissie vir Leer en Aktuele Sake opdrag om 'n studie te maak van die wese en inrigting van Geloftedag (NGK 1986a:728; 1986b:52; Strauss 2020).

'n Nuwe bedeling bring nuwe omstandighede én nuwe denke oor aktuele sake. Nuwe diskoerse ontstaan waarvan NG gemeentes nie geïsoleer kan word nie.

Froneman (2015:129) toon dat Grobler (2007:215) beweer dat die belangstelling en bywoning van Geloftefeeste onder 'n nuwe geslag Afrikaners afneem. 'Die Afrikaners' as 'n groep, van wie 
Froneman beweer dat Geloftedag in die verlede 'n sentrale plek in hulle sogenaamde volksgodsdiens ingeneem het en 'n regstreekse invloed gehad het op hul strewe om as 'n geroepe volk 'n eie afsonderlike staanplek in die wêreld te kry. Sonder 'n verwysing óf statistiese gegewens vir sy aannames, meen Froneman veralgemenend dat die tradisionele opvatting van die Afrikaner oor Geloftedag en die 'apartheidsideologie' deel uitmaak van dieselfde denkparadigma. Geloftedag is 'n onderdeel van die Afrikaner se 'nasionalistiese' diskoers (Froneman se woord vir ' $n$ verabsoluteerde Afrikanernasionalisme) en lei tot 'n beter verstaan van hoe hierdie ideologie in die 20e eeu beslag gekry het (Froneman 2015:126). Froneman koppel die gewildheid van Geloftedag aan die viering van die Gelofte van 1838 deur Afrikaners vanuit hulle 'volksgevoel', politieke invloed en 'volksgodsdiens'. Hy verbind die bestaan van die viering van Geloftedag dus aan die Afrikaner se sogenaamde volksgodsdiens, wat hy by implikasie as onbybels afwys. 'n Koppeling, wat met die bewindsoorname van die African National Congress (ANC) in Suid-Afrika in 1994 en die koms van - in die beter oomblikke van hierdie ewig geknelde land - 'n omvattende demokrasie gebaseer op 'n akte van menseregte, die wind van voor gekry het.

Verbind aan indiwiduele menseregte, word die tradisionele denke van Afrikaners oor 16 Desember ná 1994 afgeskiet vanuit 'n antigroepseie-gevoel in Suid-Afrika, en 'n vermeende rassebotsing tussen wit en swart by Bloedrivier, met die staatsnaam na 1994 vir dié dag: Versoeningsdag. Versoeningsdag, wat in Nelson Mandela se verstaan van 'n reënboognasie 'n verwerking van die vyandelikhede rondom Bloedrivier in ' $n$ proses van versoening impliseer, maar waarvan ras-ideologiese uitsprake in die regering die teendeel beklemtoon. Die klem op indiwiduele regte ten koste van 'n regsruimte vir kulturele en godsdienstige groepe, word 'n diskoers wat emosioneel ideologies nie plek laat vir die inhoud van Geloftedag nie. Inteendeel, die Handves van Regte in die Grondwet van 1996, wat as die 'cornerstone of democracy' bestempel word (Rautenbach \& Malherbe 1998:8), beskou die Suid-Afrikaanse gemeenskap as 'n aantal staatkundig saamgevoegde indiwidue wat op menswaardigheid, gelykheid en vryheid aanspraak maak (Kleyn \& Viljoen 1998:267).

Met die swanesang van apartheid in Suid-Afrika in die 1980's as agtergrond, het Afrikanerhistorici met twyfel en kritiek oor kernaspekte van die Gelofte van 1838 gekom. Vrae oor die Gelofte is gevra: die vraag na 'n geloofwaardige teks van die Gelofte; die geldigheid van so 'n gelofte vandag; die vraag na dit wat in die Gelofte aan die Here belowe is, naamlik die bou van 'n kerk, die aard en atmosfeer van die viering van dié dag, én die binding van die nageslag van die Afrikaner aan die Gelofte. Menings was uiteenlopend van aard en is in talle publikasies vervat (Botha 1988; Duvenage 1988; Marais 1996; Oberholzer 1988; Olivier 1990; Pont 1988; Snyman \& Barnard 1992; Spoelstra 1982; Strauss 1994; Van den Berg 1999; Van Jaarsveld 1979; 1987).
Die mees omstrede standpunt - in hierdie omstandighede kom waarskynlik van Van Jaarsveld (1979:1987). Hy verwys na die weergawe van Sarel Cilliers, 'n ouderling en die voorganger by die aflê van die Geloftegebed deur die Wenkommando van Pretorius op 9-16 Desember 1838 (Strauss 2001:821-824; Visagie 2012:142-143), as 'n 'onbetroubare herinneringstuk' (Strauss 2001:822; Van Jaarsveld 1979:48). Hierdie weergawe vorm die basis vir die standaardweergawe oor die Gelofte onder Afrikaners in die laaste meer as 100 jaar. Onthutste volksgenote teer en veer Van Jaarsveld daarop tydens 'n openbare geleentheid by die Universiteit van Suid-Afrika - 'n vorm van afkeur onder sekere Afrikaners (Strauss 1994:4).

In die opdrag aan sy Kommissie vir Leer en Aktuele Sake om 'n studie te onderneem na die wese en inrigting van Geloftedag op 16 Desember, 'n studie wat by die volgende Algemene Sinode (die Sinode van 1990) gereed moes wees, het die Algemene Sinode van 1986 die aktualiteit van die tema onder NG ledemate en meer algemeen. Die woorde 'wese en inrigting' dek die problematiek van die saak, en impliseer die vertroue dat die wese van die Gelofte in die nuwe Suid-Afrika nagekom kan word: dat die Gelofte van 1838 in 'n nuwe Suid-Afrika nie onwenslik of onkerklik is nie: en dat alle vorms van die viering van Geloftedag by implikasie nie sonder meer 'n voorbeeld van 'n verwerplike volksgodsdiens onder Afrikaners - à la Froneman - is nie. Meer nog, hierdie verslag word opgestel tydens 'n diskoers onder Afrikaners en lidmate van NGK gemeentes oor die saak wat die aktualiteit van die verslag verhoog. Boonop kry die NGK hiermee 'n gulde geleentheid om as 'n kerklike profeet vanuit die Woord en die reformatoriese Sola Scriptura (die Skrif alleen) in die saak leiding te gee.

Dit is op hierdie verslag en die besluite van die Algemene Sinode van 1990 oor sy aanbevelings dat hierdie artikel konsentreer. Om so 'n ondersoek te loods, moet daar skriftuurlik grondig na die Gelofte van 1838 en sy toepassing vandag gekyk word. Dit gaan om 'n bybelsverantwoorde vergelykende literatuurstudie van beide die Gelofte van 1838 en die besluite van die Algemene Sinode van 1990 oor die viering van Geloftedag vandag. Dit is ook 'n kerklik etiese oorweging daarvan. Vir 'n gereformeerde kerk om die Gelofte van 1838 as kerk van Christus reg te vier, is die regte verstaan en 'n skrifgebaseerde kerklike beoordeling daarvan nodig.

\section{Algemene Sinode 1990: Geloftedag behoort gevier te word}

Teenoor kritiese stemme teen die kerklike herdenking van die Gelofte van 1838, neem die Algemene Sinode van 1990 ter inleiding 'n positiewe besluit oor die viering daarvan. Die besluit van die Sinode impliseer 'n behoorlike deurdenking en verantwoording van die meriete van die saak wanneer hy sê dat 'Geloftedag gevier behoort te word', en dat lidmate aangemoedig moet word 'om hulle met die historiese en godsdienstige betekenis daarvan te vereenselwig' (NGK 1990a:560). 
Twee waarnemings volg uit hierdie besluit.

Die eerste waarneming is dat die Sinode hom nie begewe in debatte en verskille oor die verstaan en betekenis van aspekte van Geloftedag nie. Die vergadering kom as 'n kerkvergadering met gereformeerde soberheid en nie as 'n kenner of arbiter van die gekiedenis nie. Die vergadering beredeneer ook nie die beste teks vir die Gelofte van 1838, die praktiese implikasies daarvan vir die hede, die beste bewoording vir die Gelofte en die motivering waarom dit steeds nagekom moet word nie. Die Algemene Sinode van 1990 neem ' $n$ algemene besluit van steun aan die viering van die Gelofte, en handhaaf stilweg die viering van 16 Desember as 'n staatserkende vakansiedag met 'n godsdienstige karakter. Die Sinode weerspieël én handhaaf 'in beginsel' ('n gangbare begrip in NG-kringe) 'n algemene begrip onder Afrikanerlidmate van Geloftedag. Ter inleiding van sy motivering vir 'n besluit deur die Sinode, gee Leer en Aktuele Sake die standaardweergawe van die Gelofte van 1838 weer, waarna verwys is - sonder kommentaar. Die verslag en voorstelle van die Kommissie is dus 'n kerklike reaksie op die gangbare opvatting onder Geloftedag-Afrikaners in die NGK oor die aanpak van die saak.

Hierdie waarneming word deur 'n aanvullende besluit bevestig wat die vergadering oor die viering van Geloftedag neem.

Volgens die Algemene Sinode van 1990 moet die 'godsdienstige aspek van Geloftedag ... voorrang geniet', maar die dag kan ook met kulturele aktiwiteite gevul word (NGK 1990a:560). Die Sinode maak dus 'n keuse vir die viering van Geloftedag met godsdienstige aktiwiteite, waaronder Woordbediening en aanbidding, maar laat die deur oop vir kulturele aspekte waarin aanvaarbare kulturele aksies en -tradisies die program kan bepaal.

Die keuse vir 'godsdienstige' én 'kulturele' aspekte bevestig die aard van die bestaande Geloftefeeste onder Afrikaners. Kerkrade en feeskomitees werk saam aan 'n viering: óf die feeskomitee reël die fees in oorleg met 'n kerkraad of kerkrade en die dominees van die omgewing, óf die kerkraad reël 'n erediens alleen of in kontak met 'n feeskomitee of -komitees.

Die Algemene Sinode van 1990 leen 'n oor aan daardie stemme in die NGK wat in dié tyd pleit vir versoening in Suid-Afrika. ${ }^{1}$ Versoening is die term wat in 1994 aan 16 Desember as 'n openbare vakansiedag deur die Suid-Afrikaanse owerheid gekoppel word. Die Sinode van 1990 neem 'n tweede besluit oor Geloftedag: 'n gees van versoening moet tydens Geloftedagvierings nagestreef word (NGK 1990a:561). Die implikasie is dat 'n regte

1.In “Kerk en Samelewing - 1990' (KS-1990:10) sê die Algemene Sinode van 1990 dat versoening nie die toesmeer van verskille en goedpraat van dít wat verkeerd is, beteken nie, maar die openhartige deurpraat daarvan. In sy verslag oor Gelofteda aan die Algemene Sinode van 1990, stel sy Kommissie vir Leer en Aktuele Sake da alle inwoners van Suid-Afrika 'geroep is om ... alle vyandskap te staak en in 'n gee van verdraagsaamheid en versoening in vrede te lewe' (NGK 1990b:116). Die begrip versoening as ' $n$ Christelike oogmerk in die nuwe land, was in hierdie stadium ' $n$ aktuele term wat gereeld in diskoerse voorgekom het. verstaan van die Gelofte van 1838 en versoening in Suid-Afrika mekaar nie uitsluit nie.

Versoening moet een van die uitvloeisels van 'n bybelsgefundeerde herdenking van die Gelofte van 1838 wees. Vanuit 'n bybelse visie kan versoenend oor almal se aanvaarbare of verantwoorde eie of eie verlede as Voortrekker en Zoeloe, wit en swart nagedink word.

Hoewel 'n historiese verband tussen die Algemene Sinode van die NGK van 1990 en 16 Desember in Suid-Afrika as Versoeningsdag ná 1994 histories moeilik nagespeur kan word, saai hierdie besluit dalk 'n saadjie, of stuur dit 'n vlieër op, wat die herbenaming van dié dag in 1994 as Versoeningsdag, vergemaklik.

Op eie versoek besoek president Mandela die Algemene Sinode van 1994 op 13 Oktober 1994 en spreek hy die vergadering toe. Hy bedank die ‘leierskap van die Ned Geref Kerk' vir die konstruktiewe rol wat hulle rondom 27 April 1994 en die verkiesing in Suid-Afrika gespeel het. 'n Leiersgroep waarin professor Johan Heyns met sy klem op versoening in Suid-Afrika én sy positiewe ingesteldheid oor Geloftedag, 'n sterk rol gespeel het (NGK 1994:536). Ter bevestiging van 'n positiewe ingesteldheid in die NGK teenoor Geloftedag, as ' $n$ dag van versoening, neem die Algemene Sinode van 1994 'n 'gebalanseerde' besluit oor 16 Desember. Volgens hierdie vergadering is daar nie 'n botsing tussen die regte verstaan van die Voortrekkers se Gelofte van 1838 en versoening en vrede in Suid-Afrika nie. Die dag moet ook vanuit hierdie perspektief gevier word (NGK 1994:437).

Die tweede waarneming uit die besluit van die Algemene Sinode van 1990 is dat die NGK opnuut sy steun aan die viering van Geloftedag as primêr 'n godsdienstige feesdag toesê. Hierdie besluit toon dat hy die nuwe samelewing geestelik en emosioneel betree het en oortuig is dat hy die viering van Geloftedag op argumente van meriete in die nuwe situasie kan handhaaf. Sy keuse vir 'n viering van die dag in die nuwe bedeling met grondwetlike vryheid van assosiasie en spraak, het ruimte en is geoorloof (Kleyn \& Viljoen 1998:268-269; Rautenbach \& Malherbe 1988:13-16).

Die steun van die Algemene Sinode van 1990 aan die godsdienstige en kulturele viering van Geloftedag, word in die lig van die verslag van sy Kommissie vir Leer- en Aktuele Sake oor Geloftedag geneem. Interessant genoeg, is Johan Heyns, met sy ywer vir versoening in Suid-Afrika, die voorsitter van hierdie Kommissie (NGK 1990a:134).

\section{Algemene Sinode 1990: Die teks van die Gelofte van 1838}

Volgens die verslag van Leer- en Aktuele Sake, is die belangrikste aspek van Geloftedag sy religueuse waarde.

Hierdie Kommissie gebruik ook die standaardweergawe van die Gelofte in die Afrikanerkultuur- en kerklike kringe. 
'Hier staan ons voor die God van hemel en aarde om 'n gelofte aan Hom te doen ...' (NGK 1990a:115).

Hierdie weergawe is 'n aanhaling uit G.B.A. Gerdener (1919) se 'Sarel Cilliers: Die Vader van Dingaansdag'.

Gerdener het 'n rekonstruksie van Cilliers se Nederlandse weergawe in sy Joernaal opgeneem, wat in 1876 deur Hofstede gepubliseer is. Hofstede gebruik Cilliers se weergawe kort voor sy dood in 1871 (Gerdener 1925:112, 132). ${ }^{2}$ Cilliers se weergawe word egter deur sy biograaf, Gerdener, verwerk met wysigings wat Gerdener as 'nodig beskou' het om 'so na aan die oorspronklike as moontlik' te kom (Gerdener 1925:68). Op sy beurt vertaal W.E.G. Louw Gerdener se weergawe in 'behoorlike' Afrikaans (Kapp 1975:73). Hierdie vertaling wat tans nog 'amptelik's gebruik word, verskyn op 7 Februarie 1962 in 'n notule van die hoofbestuur van die Federasie van Afrikaanse Kultuurvereniginge (FAK) (Greyling 2019:2).

Sedertdien het twee groot besware die waarde van die Cilliers-weergawe in gedrang gebring.

Uit gesaghebbende bronne wat kort na Bloedrivier in 1838-1839 op skrif gestel is en dus nie soos by Cilliers, aan die druk van meer as 30 jaar op sy geheue, blootgestel was nie, word daar na die Gelofte as 'n gelofte in 'n gebed, verwys (Duvenage 1988:166; Strauss 1994:9-11; 2001:821-824). Wanneer Cilliers sy weergawe met 'Mijne broeders en mede-landgenoten ...' begin, kan dit dus nie 'n egte weergawe van die Gelofte wees nie. 'n Gelofte in 'n gebed spreek tog die God van hemel en aarde aan, en nie die kerklike broers en landgenote van die Republiek Natalia nie (vir die burgerskap van hierdie Republiek in Desember 1838, sien De Jongh 1977:155-156).

Wat Van Jaarsveld en ander met hierdie kritiek egter miskyk (Snyman \& Barnard 1992:117; Spoelstra 1982:7-9), is dat Cilliers hiermee vertel wat hy voor die eerste aflegging van die Gelofte op Sondag 9 Desember 1838 by Wasbank aan die Wenkommando van Bloedrivier gesê het. Sy mededeling was dat hulle daar voor die God van hemel en aarde gestaan het om 'n gelofte aan Hom te doen. Daarna het hy die inhoud van die gelofte uiteengesit. Verder het hy aan die aanwesiges gevra om die aflê van die Gelofte wat hierna gevolg het, met hom te deel. Beswaardes wat nie wil nie, moet hulself uit die voete maak. Toe niemand op hierdie versoek reageer en die byeenkoms verlaat nie (Gerdener 1925:66-67), het hy sy hande na die hemel opgehef om te bid 'in naam van ons allen'. 'n Bladsy vroeër, wys hy daarop dat daar besluit is dat hy sal voorgaan by die aflê van die Gelofte teenoor die Here (natuurlik in gebed) 'in de naam van allen ...'. Volgens

2.Onderaan Cilliers se Joernaal in Gerdener, verskyn die naam van ene W.S. van Rijneveld wat dit waarmerk as 'Een verbatim Copy'. S.A. Cilliers onderteken sy Joernaal as ' $n$ 'oud-Ouderling in Gods langmoedigheid ... door zijne genade 69 Jaren' (Gerdener 1925:132). Oud-ouderlinge kon destyds in die NGK gekombineerde kerkraadsvergaderings, wat byvoorbeeld kerkraadslede aanwys en predikante beroep, bywoon. Dit was'n gesogte titel onder getroue kerkgangers (Strauss 2019:15-16).

3.Daar is natuurlik geen gesagvolle, oorkoepelende kultuur- of kerklike instansie onder Afrikaners wat namens hulle op 'n 'aanvaarbare' teks van die Gelofte kan besluit nie.
Cilliers is die Gelofte die week van Sondag 9 tot Sondag 16 Desember 1838 'elk avond' in gebed herhaal op die drie plekke in die laer waar godsdiens gehou is (Cilliers in Gerdener 1919:121-122; Duvenage 1988:166). Boonop moes Cilliers ná die Slag van Bloedrivier op Sondag 16 Desember 1838, maan teen menslike selfverheffing na 'de belofte in onze gebeden aan onze Heer' (Cilliers in Gerdener 1919:125; De Jongh 1987:169). In 'n brief aan ds. Van Broekhuizen van Kroonstad in 1866, bevestig Cilliers dat die Gelofte van 1838 in 'n gebed aan die Here gedoen is (Liebenberg 1977:33; Strauss 2001:823). Die vraag wat dus gevra word, is die volgende: hoe anders as deur gebed, kommunikeer 'n mens met die Here oor ' $n$ gelofte? Ouderling of oud-ouderling Cilliers sou dit beslis geweet het ...

Cilliers se 'Mijne broeders en medelandgenoten ...' is dus nie deel van die Gelofte nie. Dit is Ciliers se aanpreekvorm van die laer om hulle in te lig waaroor die eerste aflê van die Gelofte, wat op hierdie mededelings sal volg, sal gaan (Cilliers in Gerdener 1925:121). Hy bevestig dus 'n voorneme waaroor almal wat hier teenwoordig is, waarskynlik reeds deur hulle direkte leiers in die kommando ingelig is. Dit is ondenkbaar dat die aanwesiges nie geweet het waarvoor hulle bymekaarkom nie. 'n Gelofte aan die Here is te ernstig om dit sonder voorafkennis of -inligting van wat gaan gebeur, by hulle wat dit moet aflê, aan te pak. Boonop was Cilliers daarvan oortuig dat die Geloftegebed in die 'naam van allen' moet geskied: dit wil sê, met die instemming en goedkeuring van almal teenwoordig. Dit sou onmoontlik wees sonder die voorafinligting en -toetsing van die kennis en positiewe gesindheid van almal.

Die tweede groot beswaar is teen Cilliers se beskrywing van die viering van 16 Desember, as 'zoo als een Sabbath' (Cilliers in Gerdener 1919:121).

Die drie mees gesaghebbende bronne vir die Gelofte van 1838, is Cilliers se Joernaal uit die 1870's, Andries Pretorius se brief aan die Natalse Volksraad 'n week ná die Slag op 23 Desember 1838, en die Joernaal van die sekretaris van die Wenkommando, Jan Bantjes, oor die wedervarings van hierdie kommando kort na die afloop daarvan (Strauss 2001:821-822).

Die Gelofte was na alle waarskynlikheid die hoogtepunt van Cilliers se lewe en hy en Erasmus Smit, die Voortrekkerpredikant, was moontlik die enigstes wat dit direk na 1838 getrou herdenk het. Op hierdie feeste van godsdienstige aard, is historiese vertellings op die Cilliersfees bygevoeg, om die geskiedenis lewend te hou (Gerdener 1925:109; NGK 1990a:1115). Hierdie soort viering én die feit dat hy die geraadpleegde voorganger by die eerste aflê van die Gelofte was, het Cilliers waarskynlik gehelp om besonderhede rondom 16 Desember beter te onthou. Nog 'n gesaghebbende bron is die brief of verslag van die bevelvoerder (of hoofkommandant) van die Wenkommando by Bloedrivier en die inisieerder van die Gelofte van 1838, Andries Pretorius, aan die Natalse Volksraad op 23 Desember 1838. Die kort tydsverloop van die brief ná die Slag en 
Pretorius se sentrale rol in die Wenkommando, plus sy inisiatief by die aflê van die Gelofte (Duvenage 1988:141), gee aan dié brief meer historiese gesag. Pretorius was by die oorhoofse of gesamentlike aksies van die kommando in 'n sentrale en strategiese posisie. Voeg hierby die Joernaal van die sekretaris van die kommando, Jan Bantjes, wat eweneens op 'n sentrale punt in die kommando was, en wat die Gelofte na bewering reeds op 9 Desember 1838 as die dag waarop dit die eerste keer afgelê is, in sy Joernaal aangeteken het (Greyling 2019:1). Die Joernaal is op 14 Junie 1839 in De ZuidAfrikaan gepubliseer (uiteensetting van bronne by Strauss 2001:821-822, 832-834). Indien hierdie bronne dit eens het oor 'n saak rondom 16 Desember 1838, verhoog dit die waarskynlikheid daarvan.

Indien die saak waarom dit hier gaan in dieselfde rigting neig, selfs al gebruik hulle nie dieselfde terme vir sake nie, is die kanse groot dat bewoordings wat verskil, versoenbaar is. As Pretorius byvoorbeeld gewag maak van 'n dag aan die Here toegewy en met danksegginge gevier, en Bantjes van 'n dag tot eer van God herdenk en Cilliers van 'n bid-, gedenk- en dankdag, klink dit alles na Sarel Cilliers se 'zoo als een Sabbath'. Dit gaan by almal immers om die gees waarin die dag herdenk moes word (vgl Bantjes 1839; Cilliers 1866; Pretorius 1839). ${ }^{4}$ Hier is ook nie sprake van 'n Boereverwaandheid wat 'n 53e Sondag probeer skep wat indruis teen die 52 Sondae per jaar van God as Skepper nie. Maar 'zoo als een Sabbath' is hoe Christen-Afrikaners godsdienstige of kerklike feesdae op weeksdae in die verlede benader het, en tot ' $n$ mate steeds benader (De Jongh 1987:164; Duvenage 1988:166-167). As Bantjes en Pretorius dan op hierdie punt teenoor Cilliers afgepeel móét word, as dit die aanvaarde metode is, waarom nie Pretorius en Bantjes ook teenoor mekaar afspeel nie? Dit is immers konsekwent.

Opgesom kom hierdie verwysing na tekste vir die Gelofte van 1838 daarop neer dat die Kommissie vir Leer en Aktuele Sake se gebruik van die aanvaarde standaardteks (die FAK-teks) van die Gelofte, uit 'n historiese oogpunt nie waterdig is nie, maar tog nie tot die ontsporings oor kernsake hoef te lei nie. Daar is nie 'n goedgekeurde standaardteks (of 'n harde kopie) van die Gelofte nie, maar hierdie drie gesaghebbende weergawes, waarvan die FAKteks een is, bevat versoenbare verskille in die bewoording van die sake (Duvenage 1988:166).

\section{Algemene Sinode 1990: Die noodsaak van die Gelofte van 1838}

Die teks van die Gelofte van 1838 wat in die verslag van Leer en Aktuele Sake aan die Algemene Sinode van 1990 opgeneem is, suggereer en bevestig dus die godsdienstige aard van die herdenking of viering van die Gelofte van 1838. Volgens hierdie weergawe, is daar gebid om 'n oorwinning oor 'ons vyand'. Indien die Here die gebed verhoor, beloof die

4.As die Nasionale Regering in Suid-Afrika in 1952 sekere bepalings van die 'sabbatswetgewing' op 16 Desember (nou herdoop tot Geloftedag), van toepassing maak, sê die betrokke minister, dr T.E Dönges, dat dit nie hier om 'n mensgemaakte maak, sê die betrokke minister, dr T.E Dönges, dat dit nie hier om 'n mensgemaakte die Volksraad dele 74-76:10435-10438)
Wenkommando drie dinge om: (1) die dag en datum - dit sou 16 Desember wees - elke jaar as 'n dankdag soos 'n sabbat deur te bring, (2) 'n huis tot Gods eer op te rig waar dit Hom behaag - ten spyte van 'n moeilike geskiedenis, die bestaande Geloftekerkie in Langmarkstraat in Pietermaritzburg (Greyling 2019:3) - en (3) dit aan ons kinders mee te deel om met ons daarin te deel tot in die opkomende geslagte. Die teks sluit af met die sin dat die 'eer van sy Naam verheerlik sal word deur die roem en die eer van die oorwinning aan Hom te gee' (NGK 1990a:115). Leer en Aktuele Sake konsentreer veral op die eerste en derde belofte aan die Here: die gees van die viering van die dag en die wyse waarop die Gelofte van 1838 mense aanspoor of geestelik moreel bind. Daarop word later teruggekom.

Genoemde gesaghebbende bronne oor die Geloftegebed dui aan dat die volgende in die Gelofte van 1838 uitgespreek is: die Here is in die gebed aangespreek; die voorneme van 'n gelofte is aan Hom genoem; 'n oorwinning oor die vyand - die Zoeloekrygers van koning Dingaan - is afgesmeek; en in antwoord hierop is die bou van 'n kerk, die viering van die dag en die betrek van die nageslag by die saak, aan die Here belowe (Strauss 2001:824). Met hierdie histories gegronde weergawe, moes die Algemene Sinode van 1990 oor die wese en inrigting van Geloftedag besluit en moes die Algemene Sinode - 1990 'n sinvolle kerklike stem laat hoor.

Die slotsin van die FAK-teks, naamlik die 'eer van sy Naam sal verheerlik word ...', vat die geestelik godsdienstige aard van die Gelofte van 1838 saam. Dit is dus nie vreemd dat die Kommissie vir Leer en Aktuele Sake, as deel van die NGK, in sy verslag aan die Algemene Sinode van 1990, hierdie saak as 'die belangrikste aspek' van 16 Desember as 'Geloftedag' uitwys nie. Wat ook opvallend is, is dat hierdie Sinode in sy aangeduide verrekening van 'n nuwe bedeling in Suid-Afrika, nie torring aan 'Geloftedag' as die naam van die dag waarop die Gelofte van 1838 herdenk moet word nie. Die regeringsverandering in 1994 van Geloftedag na Versoeningsdag, maak in elk geval nie die gebruik van 'Geloftedag' deur die NGK 'onwettig' nie. Die gebruik van 'n ander term (naam) vir die viering van 16 Desember in sekere kringe in Suid-Afrika, beteken nie dat die staatsreëling as 'n reëling vir die staatsgemeenskap wetlik ter syde gestel word nie. Die vryheid van spraak en assosiasie soos vervat in die Grondwet van 1996, word gehandhaaf (Rautenbach \& Malherbe 1994:13-16). Die wese en inrigting van Geloftedag met die Gelofte van 1838 aan God-Drieënig, is sedert 1838 nog nooit deur die voorskrifte van die staatsowerheid alleen bepaal nie. 'n Verandering aan die naam wat die staat vir die dag het, reflekteer buitendien dit wat in die gemeenskap funksioneer. Dit is boonop ondenkbaar dat 'n instansie wat nie met die Gelofte assosieer nie, alleen die naam van die dag wat Afrikaners daarvoor of vir hulle feeste gebruik, moet bepaal.

In die Nederlandse Nadere Reformasie met sy sogenaamde 'oude schrijvers', is die aflê van 'n gelofte aan die Here - Sarel Cilliers noem dit 'n belofte aan die Here (Cilliers in Gerdener 1925:121) - geoorloof in 'n situasie waarin daar werklike 
nood is. 'n Belofte of gelofte of erewoord aan die Here is nie 'n ligtelike saak nie, en die situasie moet dringend wees (Strauss 2001:820). Onder Andries Pretorius en kie op die trekpad was Wilhelmus à Brakel die mees gelese skrywer van die Nadere Reformasie. In sy Redelijke Godsdienst rondom 1700 , praat hy van die aflê van geloftes, of soos hy dit ook noem, beloftes aan die Here (Strauss 2001:819). Dit is 'n saak wat nie vreemd is aan Calvyn en die gereformeerde tradisie nie (Calvyn IV sa:13.1; Polyander 1966:45-53).

Vir À Brakel is geloftes deel van die Christelike lewe. Dit het 'n geestelik godsdienstige kant. Hy hanteer dit by temas soos vas, sang, naasteliefde en nederigheid. Binne die genadeverbond kan die gelowige hom deur 'n gelofte aan God verbind om - en dit is belangrik - na sy wil regeer te word. À Brakel 11 (s.a.) stel dat:

Eene gelofte is eene verbintenis aan God om eene particuliere goede zaak, die in onze macht is, uit vrije wil te doen of te laten tot dankbaerheyt of tot bevorderinge van onzen geestelijke welstand. (bl. 516).

Vir À Brakel gaan dit daarom om met 'n saak na die Here te gaan wat die toets van die lig kan deurstaan, binne die mens se vermoë is, én - dit is in 1990 steeds belangrik - met 'n vrywillige vereenselwiging daarmee. 'n Gelofte moet nie ligtelik gemaak word nie en hulle wat dit doen, moet seker wees dat dit nagekom kan word. Die Skrifaanhalings wat Cilliers vir die nakoming van die Gelofte van 1838 gebruik dit het sy instemming met die gedagte van 'n gelofte by Pretorius aanvanklik verhoed ${ }^{5}$ - kom ook by À Brakel voor: Psalm 76:12 se 'Doet geloften en betaalt ze den Heere uwen God' en Prediker 5:4 se 'Het is beter dat gij niet belooft, dan dat gij belooft en niet betaalt' (À Brakel II sa:517; De Jongh 1987:162). À Brakel se stelling dat'n gelofte deur die gelowige gebruik word om homself opnuut aan God te wy, of die hulp van die Here in 'n noodsituasie in te roep, het waarskynlik inslag by die Trekkeremigrante gevind. Daar loop 'n aantoonbare lyn van À Brakel na persone soos Cilliers en Pretorius (Strauss 2001:821).

Die nodigheid van 'n gelofte deur die Trekkers in Natal in die sogenaamde bloedjaar van 1838, word deur verskeie woordvoerders onderstreep. De Jongh praat van hulle 'benarde posisie'. Retief en sy geselskap is in Februarie by Umgungundlovo vermoor; meer as 500 mense uit die Trekgeselskappe gesamentlik is daarna in die Groot Moord van middel Februarie 1838 omgebring; die Vlugkommando het in April misluk; Dingaan het die Engelse in Port Natal verslaan waar 13 Engelse en 1000 Zoeloes dood is; ongeveer 25000 beeste is in Augustus by Veglaer gebuit; die Trekkers was in drie laers, naamlik Modder-, Sooi- en Veglaer vasgekeer en die Britse Regering in die Kaapkolonie het sake vir die emigante bemoeilik. In September 1838 is die uitvoer van wapens, ammunisie én lewensmiddels na die Trekkers verbied, en op 3 Desember 1838 is die hawe van Durban deur die Engelse geblokkeer (De Jongh 1987:156).
De Jongh1987) eindig sy betoog veelseggend, en hy beskou die Gelofte van 1838 as 'n laaste moontlike uitweg:

Vir die Voortrekkerkommando was dit 'n stryd om oorlewing teen alle kanse en teen 'n oormag. Daarom het hulle hul op God beroep ... (bl. 156)

Visagie (2012:142) wys op die volgende. Die Trekkers was teen November 1838 sonder hulle belangrikste leiers. Retief (Februarie 1838) en Uys (April 1838) is deur die Zoeloes vermoor of gedood, Potgieter is daarna terug oor die Drakensberge en Maritz is op 23 September 1838 weens siekte oorlede. Positiewe klanke is eers in November 1838 gehoor toe Andries Pretorius in die laers verwelkom is.

Gekoppel aan die ingesteldheid van die Boere-emigrante en die geestesklimaat waarin die Gelofte van 1838 afgelê is, het hierdie noodsituasie meegebring dat die tog van die Wenkommando na Bloedrivier en Dingaanstat, einde November begin Desember 1838, volgens 'n ooggetuie, meer na 'n 'bedevaart dan een krijgstocht' gelyk het. Op 05 Desember 1838 het kommandant Pretorius aan die Wenkommando in die omgewing van Ladysmith gesê dat hulle as 'n Christenkommando ' $n$ beslissende veldslag tegemoet gaan. Daarom moet hulle 'n gedugte, gedissiplineerde en vasberade gevegsmag wees. Die een wat verloor, sal sy tente moet verskuif en Natal moet verlaat (Duvenage 1988:140-141).

In hierdie omstandighede het die meriete van 'n gelofte aan die Here die Wenkommando en sy leiers oortuig.

Wat meer is, die kwessie van 'n gelofte aan die Here en sy redding uit 'n noodsituasie met die oog op die vestiging van 'n Christelike gemeenskap tussen die see en die Drakensberge, was 'n Trekkerprioriteit. Die inhoud van die Gelofte sou ook sterk blyke van so 'n vestiging gee. Daarvoor het Retief met Dingaan onderhandel, ten einde 'n geregverdige, erkende grondgebied vir die Trekkers se reisende 'Maatschappij', De Vrije Provincie van Nieu Holland in Zuid Oost Afrika, te bekom. Teen Mei of Junie 1838 is die Trekkerrepubliek van Natalia in Natal gevestig. ${ }^{6}$

\section{Algemene Sinode 1990: Gebind aan die godsdienstige aard van die Gelofte van 1838}

In die motivering van die godsdienstige aard van Geloftedag, wys die verslag van Leer en Aktuele Sake aan die Algemene Sinode van 1990 daarop dat die Gelofteteks 'telkens gewag ... maak van die eer van God'. Die begrip 'eer van God' is 'n struktuurdraer van die betekenis van die Gelofte van 1838. God Drie-enig verdien die roem en eer vir die verloop van die Slag van 16 Desember 1838. Volgens die Kommissie is die godsdienstige aard van die Gelofte deurgaans deur Erasmus Smit en Sarel Cilliers beklemtoon. 'Dit is die primêre betekenis van Geloftedag' (NGK 1990a:115).

6.Kyk Van Schoor en Van Rooyen (1960:58-59) vir gedetailleerde inligting 
Pretorius se dag wat aan God toegewy en met dank - aan Hom - gevier word, Bantjes se dag wat tot eer van God herdenk word, en Cilliers se bid-, gedenk, en dankdag 'zoo als een Sabbath', bevestig die Kommissie se verstaan van die primêre betekenis van Geloftedag. Dit gaan hier om 'n dag met 'n godsdienstige inslag waarin die eer van God voorop staan en Hy geëer en gedank word. Daarom opper Cilliers in sy Gelofte - na meer as 30 jaar van herhaling - moontlik die geykte slotsin: 'Want de eere van Zijn naam ... zal verheerlijk worden dat de roem en eer van overwinning, aan Hom zal worden gegeven'. Met hierdie sin gee die ouderling of voorganger ook sy diepste vertolking van die viering van die dag. 'n Vertolking wat gesag dra omdat Cilliers se weergawe van die Gelofte gesag dra (Cilliers in Gerdener 1925:122).

Die godsdienstige en aanbiddingsaard van die Gelofte van 1838 blyk ook uit ander faktore.

Volgens die verslag van Leer en Aktuele Sake van 1990, is die Gelofte afgelê vanweë ernstige nood in 'n krisissituasie. Deur 'die wonderlike ingrype van God, word gebede verhoor'. Bloedrivier getuig van, let wel, 'gebedsverhoring en die krag van God'. Deur nadenke oor die Gelofte, word die besef dat die nadenkers van God afhanklik is, gestimuleer. Uit menslike dankbaarheid moet die voorsienigheid van God 'verheerlik word'. Die Gelofte van 1838 leer die nageslag om hulle vertroue in alles 'op die lewende God te stel'.

Leer en Aktuele Sake plaas die gebeure by Bloedrivier in koninkryksperspektief. Volgens die Kommissie was dit nie soseer Afrikaners of Blankes oor Zoeloes of swart mense nie. Dit was die genadige beskikking van God om die Christendom in 'hierdie land' te vestig (NGK 1990a:115). Daarom word 'alle inwoners geroep om met 'n Christelike gesindheid alle vyandskap te staak en in 'n gees van versoening en verdraagsaamheid in vrede met mekaar te lewe' (NGK 1990a:116).

Die 'sabbatsklousule' van Cilliers maak nie van Geloftedag 'n 53ste Sondag nie. Dit kan ook nie van alle Christene in Suid-Afrika verwag word om daaraan 'n Sondagskarakter te gee nie. Leer en Aktueel sê: 'Ons kan niemand dwing om aan ons fees deel te neem nie'. Dit gaan om mense wat - dit is belangrik omdat die element van dwang ontbreek - hulle vrywillig met die 'karakter van die dankdag vereenselwig'. Die karakter van Geloftedag vereis dat lidmate in die posisie gestel moet word - dit is die NGK se verantwoordelikheid om 'n erediens by te woon. Indien ander instansies nie so iets reël nie, moet die kerkraad daarvoor instaan. Die Algemene Sinode van 1986 het besluit dat gemeentes vir sulke geleenthede vir lidmate voorsiening moet maak. Geloftedag het ' $n$ historiese en ' $n$ kulturele kant, maar hierdie aspekte is nie die verantwoordelikheid van die kerk nie. Die viering van die dag mag ook nie 'n platform bied vir partypolitieke of nie-kerklike propagandistiese oogmerke nie. Die eenheid van die geloof in God trek mense van verskeie politieke oortuigings saam. Die godsdienstige aard van Geloftedag is die saambindende faktor van mense wat 'andersins' van mekaar verskil.
Ten opsigte van die bou van 'n kerk en die betrokkenheid van die nageslag by die viering van die Gelofte van 1838, sny die Kommissie sy verslag kort.

Volgens Leer en Aktuele Sake is die belofte om vir die Here 'n kerk te bou, reeds met die inwyding van die Geloftekerkie in 1841 uitgevoer (Greyling 2019:3; NGK 1990a:116). Wat die binding van die nageslag aan die Gelofte betref, kom die Kommissie met 'n saak wat by À Brakel, Pretorius én Cilliers aanwesig is, maar met die viering van die Gelofte deur die gemeenskap, veral na 1864, geïgnoreer is: die wyse waarop mense deur die Gelofte van 1838 gebind word. Die Kommissie reken dat diegene wat hulle nie met die strekking van die Gelofte kan vereenselwig nie, nie daartoe gedwing kan word nie. Geen mens kan 'n ander mens deur 'n gelofte aan God wat as 'n gebed uit die hart moet kom, bind nie. 'n Gelofte is 'n persoonlike onderneming onder leiding van die Gees voor die aangesig van die Here. Net die lede van die nageslag of volksgenote wat hulle uit oortuiging met die godsdienstige en historiese betekenis van Geloftedag vereenselwig, het 'n morele verpligting om dit te na te kom. As sulke Christene nie die konsekwensies van hulle oortuigings uitleef nie, is daar 'n geestelike skroef los.

Die Trekkers in die Wenkommando was kerklidmate en aanvaarde belydende gelowiges wat hulle uit oortuiging met die doel van die Kommando kon identifiseer. Daarom sou elkeen van hulle, formeel gesproke, die Gelofte kon aflê. Die vraag is egter of die drie Engelse en ongeveer 60 swart mense wat by die Wenkommando was, ook hierby ingeval het en of alle Afrikaners en hulle nageslag, ook diegene in die Kolonie wat teen die trek gekant was, hieronder geplaas moet word? Hoe dit ook al sy, alle aanwesiges én hulle wat vrywillig met die Gelofte assosieer, kon by die saak inval. Ook immigrante soos die Van Wouws en Verwoerds wat hulle later met die Gelofte vereenselwig het.

\section{Algemene Sinode van 1990: Gelofte 'n vrywillige vereenselwiging}

Dit is so dat À Brakel vanuit die Nadere Reformasie as 'oude schrijver' uit die wakis op die trekpad, praat van 'n vrywillige vereenselwiging met 'n groepsbelofte. Sarel Cilliers het volgens eie getuienis by die eerste aflegging van die Gelofte van 1838 ook aan sy toehoorders, of die Wenkommando, die keuse gegee om die vergadering te verlaat indien hulle as indiwidue nie die Gelofte wil aflê nie. Bantjes toon dat Pretorius die Gelofte net wou laat aflê 'indien allen wel wilden'. Die Gelofte is eventueel met 'algemeen toestemming', of eenparig, deur die Wenkommando afgelê (Bantjes 1839; De Jongh 1987:161).

Die Algemene Sinode van 1990 besluit ook dat Geloftedag gevier 'behoort' te word (let wel) deur lidmate wat hulle met die historiese en godsdienstige betekenis daarvan vereenselwig (NGK 1990a:116). Daarmee hanteer die Sinode die Bybels-prinsipiële vraag na die binding van die Gelofte van 1838 én die histories nuwe Suid-Afrika - 'n land 'oop' vir almal. Jy kan nie geestelike buitestanders wetlik oortuig of 
dwing om die Gelofte van harte te onderskryf nie. So skep jy ruimte vir diegene - ook in Suid-Afrika - wat nie met die Gelofte van 1838 identifiseer nie. Die Sinode glo egter dat Geloftedag 'n morele verpligting op diegene plaas wat hulle daarmee vereenselwig. Dat jou instemming met die wese van die dag, en by implikasie jou identifisering met die mense by die dag betrokke en hulle algemene lewenskyk op sake, jou moreel verplig om die dag te onderhou. 'n Verpligting wat jy net met groot verleentheid kan ontduik.

Die godsdienstige aard van die Gelofte van 1838 blyk uit drie dinge wat aan die Here beloof is: 'n kerk, 'n jaarlikse godsdienstige viering daarvan, en die oordra van hierdie viering aan die nageslag. Dit gaan om 'n vrywillige, hartlike instemming met die Gelofte van 1838 deur almal in die opkomende geslagte van die Boere-emigrante van Bloedrivier, én hulle wat daardeur moreel aangespreek voel.

Behalwe die kerklik godsdienstige betrokkenheid wat 16 Desember met sy godsdienstige betekenis impliseer, toon die Trekkers se belofte om vir die Here 'n kerk te bou op 'n plek wat Hy sal aanwys - in hulle pionersomstandighede was daar nie 'n kerk gebou nie - die geestelike grondslag van die gemeenskap wat die Trekkers tussen die see en die Drakensberge wou vestig. Die godsdienstige aard van die Geloftegebed en dit wat aan die Here beloof is, dui op die vestiging van 'n Christelike samelewing - 'n samelewing gebou op Christelike lewenswaardes - in hierdie deel van die wêreld. Tipies van dorpsvorming deur die Trekkers, is dat die kerk - merendeels die NGK - die middelpunt van die uitleg vorm. Dat die dorp rondom die kerk as die middelpunt uitgelê word (Preller II 1920:106), en die bou van 'n kerk iewers in die middel die moontlike koms van 'n dorp na hierdie plek bevestig, én daarop dui dat die gemeenskap wat hier wil woon God as die middelpunt van die lewe bely. Die nege Vetrivierse bepalings van Trekkers in Junie 1837 naby die latere Winburg, bevestig hierdie lyn. Die eerste van die nege artikels vir die nuwe staatsgemeenskap begin met 'Wij die gerreformeerde Leedematen ...'. Hulle is 'n nuwe gemeenskap met die naam die 'Vrije Provincie van Nieu Holland in Zuid Oost Africa', wat almal belydende Christene is en as gereformeerdes die Here God sentraal stel in hulle lewenswandel (Preller II 1920:102, 300).

By implikasie het die Gelofte met die drie dinge wat aan die Here beloof is, aan die Here die vestiging van 'n Christelike gemeenskap, gebou op Christelike lewenswaardes, belowe. 'n Samelewing in die gees van die Nadere Reformasie soos dit stam uit die Hervorming van die 16de eeu. ' $n$ Gereformeerd Calvinistiese gemeenskap wat sy aanhangers uit meer mense as Christen-Afrikaners trek. Natuurlik is Bloedrivier histories gekoppel aan Christen-Afrikaners en diegene wat met hulle assosieer. Die algemeen Christelike aard van geloftes, naamlik die nie-kultureelbeperkte inslag daarvan, beteken egter dat Christene uit verskillende kulture mekaar mét hulle geloftes kan respekteer én kan hande vat op daardie gebiede waarby hulle saam betrokke is.
Die Gelofte van 1838 lê beslis die fondament vir 'n Christelike versoening tussen mense. 'n Versoende gemeenskap wat verenig rondom die noodsaak van 'n kerk. 'n Konsekwente gemeenskap wat draai om die God van die Bybel as die middelpunt van sy lewe ... 'n Gemeenskap wat hulle assosieer met die slotsin van die Cilliers-weergawe van die Gelofte van 1838 soos vervat in die verslag van Leer en Aktueel aan die Algemene Sinode van 1990: ' . . die eer van sy Naam sal verheerlik word deur die roem en die eer van oorwinning aan Hom te gee' (NGK 1990a:115).

\section{Slot}

Die feit dat die Gelofte van 1838 in 'n gebed aan die Here afgelê is, én Cilliers se bygevoegde slot wat handel oor die eer en roem wat aan die Here gegee word - hoe anders kan dit as deur lied en gebed? - toon dat die viering van Geloftedag op 16 Desember primêr 'n godsdienstige viering is. Dat Geloftedag à la Cilliers mik op die roem en die eer van God Drie-enig deur 'n godsdienstige feesdag wat uit dankbaarheid aan God gewy word. Die gebruik om by hierdie viering verwante kulturele aktiwiteite te voeg waarin daar ruimte vir ' $n$ 'korrekte' weergawe van die geskiedenis gegee word, is natuurlik ook aanvaarbaar.

Leiers by die eerste aflegging van die Gelofte van 1838, Andries Pretorius en Sarel Cilliers, gaan in hulle weergawes daarvan uit dat diegene wat die Gelofte aflê, moreel of innerlik van die meriete daarvan oortuig moet wees. 'n Gelofte word in gebed aan God afgelê en die inhoud daarvan, soos die inhoud van alle gebede tot God, moet uit die hart of uit die oortuiging van die bidder(s) kom. ${ }^{7}$ Hoewel die Gelofte van 1838 deur die Wenkommando in 'n gesamentlike openbare gebed afgelê is, moes elkeen wat saambid, van die inhoud oortuig wees om daarop 'amen' (dit is waar) te kon sê (vir amen in gebed, kyk 1 Kor 14:16). Volgens gesaghebbende bronne is die Geloftegebed eventueel met die algemene instemming van die Wenkommando gedoen.

Die Gelofte van 1838 bind sy betrokkenes moreel aan die bevordering van 'n Christelike samelewing of Christelike waardes: ook in die 21ste eeu. Dit maak 'n morele appèl op diegene wat dit nakom en plaas 'n morele eis vir die viering daarvan op hulle wat met die Trekkers van 1838 moreel en histories identifiseer. ' $n$ Eis wat net in skaamte verontagsaam kan word. Die Gelofte van 1838 bind moreel en verplig niemand fisiek of uit volks- of rasse-oorwegings nie.

Die besluite van die Algemene Sinode van 1990 van die NGK oor die wese en inrigting van Geloftedag kan hieroor geraadpleeg word.

\section{Erkenning}

P.J.S. was die enigste outeur betrokke by die skryf van hierdie artikel.

7.Die Heidelbergse Kastegismus, vraag 117, handel oor die vraag: Hoe moet'n gebed wees wat God behaag en deur Hom verhoor word? Die antwoord sluit onder meer wees wat God behaag en deur Hom verhoor word? Die antwoord sluit onder meer Hy ons beveel het om te bid' (NG Kerk-Uitgewers 1982:73). 


\section{Mededingende belange}

Die outeur verklaar dat daar geen finansiële of persoonlike verbintenis is met enige party wat hom nadelig kon beïnvloed in die skryf van hierdie artikel nie.

\section{Outersbydrae}

P.J.S. was die enigste outeur betrokke by die skryf van die artikel.

\section{Etiese oorwegings}

Hierdie artikel het alle etiese standaarde vir navorsing gevolg.

\section{Befondsing}

Hierdie navorsing het geen spesifieke toekenning ontvang van enige befondsingsagentskap in die openbare, kommersiële of nie-winsgewende sektore nie.

\section{Data beskikbaarheid}

Die outeur bevestig dat die data wat die bevindings van hierdie studie ondersteun, beskikbaar is in die artikel.

\section{Vrywaring}

Die sienings en menings wat in hierdie artikel uitgedruk word, is dié van die outeur en weerspieël nie noodwendig die amptelike beleid of posisie van enige geaffilieerde verwantskap van die outeur nie.

\section{Literatuurverwysings}

À Brakel, W., s.a., Redelijke Godsdienst, Deel I en II, Bolle, Rotterdam.

Bantjes, J., 1839, 'De uitgewekene Boeren te Port Natal', De Zuid-Afrikaan, 14 Junie 1839.

Botha, S.J., 1988, 'Die Gelofte van 1838 soos dit in 1880 by Paardekraal met ' $n$ gelofte bevestig is', in A.D. Pont (red.), Die Gelofte van 1838, bl. 63-82, Kital, Pretoria.

Calvyn, J., s.a., Institutie IV, 4e dr., Meinema, Delft.

Cilliers, S.A., 1866, Brief aan ds. Van Broekhuizen (14:02:1866), Lêer A 121 Argiefbewaarplek, Bloemfontein.

De Jongh, P.S., 1977, Die lewe van Erasmus Smit, HAUM, Pretoria.

De Jongh, P.S., 1987, Sarel Cilliers, Perskor, Johannesburg.

Duvenage, G.D.J., 1988, Die Groot Trek die eerste drie jaar-Die Gelofte, Sigma-Press, Pretoria.

Froneman, J.D., 2015, 'Die Kerkbode en die viering van Geloftedag 1910-2010', Stellenbosch Theological Journal 1(1), 125-150.
Gerdener, G.B.A., 1925, Sarel Cilliers die vader van Dingaansdag, 2e druk, Van Schaik, Pretoria.

Greyling, J., 2019, Eensgesind, s.n., s.I.

Grobler, J., 2007, Uitdaging en antwoord - 'n Vars perspektief op die evolusie van die Afrikaners, Grourie, Brooklyn.

Kapp, P.H., 1975, 'Geloftefees', in P.W. Grobbelaar (red.), Die Afrikaner en sy kultuur, Deel III, Ons volksfeeste, pp. 46-97, Tafelberg, Kaapstad.

Kleyn, D. \& Viljoen, F., 1998, Beginnersgids vir Regstudente, 2 de uitg., Juta, Kenwyn.

Liebenberg, B.J., 1977, Andries Pretorius in Natal, Pretoria, Academica.

Marais, W., 1996, Geloftedag en die Afrikaner, Anrics, Pretoria.

Nederduitse Gereformeerde Kerk (NGK), 1986a, Handelinge van die 7e Algemene Sinode, s.n., s.l.

Nederduitse Gereformeerde Kerk (NGK), 1986b, Kerk en Samelewing - 1986 (KS-1986), NG Sendingpers, Bloemfontein.

Nederduitse Gereformeerde Kerk (NGK), 1990a, Handelinge van die 8e Algemene Sinode, s.n., s.l.

Nederduitse Gereformeerde Kerk (NGK), 1990b, Kerk en samelewing - 1990 (KS-1990), NG Sendingpers, Bloemfontein.

Nederduitse Gereformeerde Kerk (NGK), 1994, Handelinge van die 9e Algemene Sinode, s.n., s.l.

NG Kerk-Uitgewers, 1982, Ons glo ... Die Drie Formuliere van Eenheid en ekumeniese belydenisse, NG Kerk-Uitgewers, Kaapstad.

Oberholzer, J.P., 1988, '1835-1838: 'n Kort oorsig oor die aanloop tot die Gelofte en die Slag van Bloedrivier', in A.D. Pont (red.), Die Gelofte van 1838bl. 1-26, Kital, Pretoria.

Olivier, S.P., 1990, Fokus op die Gelofte, NG Kerkboekhandel, Pretoria.

Polyander, J., 1966, 'Over de geloften', in J. Boersma, Synopsis (2) of oversicht van de zuiverste theologie, bl. 45-53, s.n., Enschede.

Polyander, J. 1966, 'Over de geloften' Synopsis (2) of oversicht van de zuiverste theologie, Vertaal deur D. van Dijk, Boersma, Enschede, 45-53.

Pont, A.D., 1988, 'Die Gelofte van 1838 - 'n Poging om die teologiese agtergrond daarvan te peil', in A.D. Pont (red.), Die Gelofte van 1838, bl. 38-53, Kital, Pretoria.

Preller, G.S., 1920, Voortrekkermense II, Nasionale Pers, Kaapstad.

Pretorius, A.W.J., 1839, 'Brief aan die Volksraad', De Zuid-Afrikaan, 16 Februarie 1839.

Rautenbach, I.M. \& Malherbe, E.F.J., 1988, What does the constitution say?, Van Schaik, Pretoria.

Snyman, S.D. \& Barnard, S.L., 1992, 'Gedagtes oor Geloftedag', Acta Theologia 12(2), $113-119$.

Spoelstra, B., 1982, Kan Geloftedag oorlewe? PU vir CHO, Potchefstroom.

Strauss, P.J., 1994, Geloftedag in die 'nuwe' Suid-Afrika, Drufoma, Bloemfontein.

Strauss, P.J., 2001, 'Nogeens: Die agtergrond, inhoud en implikasies van die Gelofte van 1838', Hervormde Teologiese Studies 57(3 \& 4), 814-834.

Strauss, P.J., 2019, Die bome roep, die klowe roep, s.n., s.I.

Strauss, P.J., 2020, 'Die NG Kerk se afskeid van apartheid: Cottesloe (1960) 'n voorloper van 'Kerk en samelewing' (1986, 1990)?', In die Skriflig 54(1) a2529. https://doi. org/10.4102/ids.v54il.2529

Van den Berg, M., 1999, Geloftesterk jou stand, Radio Pretoria, Pretoria.

Van Jaarsveld, F.A., 1979, Die evolusie van apartheid en ander geskiedkundige opstelle, Tafelberg, Kaapstad.

Van Jaarsveld, F.A., 1987, 'Die eerste openbare viering van 16 Desember', Tydskrif vir Geesteswetenskappe 27(1), 42-49.

Van Schoor, M.C.E. \& Van Rooyen, J.J., 1960, Republieke en Republikeine, Nasionale Boekhandel, Kaapstad.

Visagie, J., 2012, 'Uittog en vestiging van die Voortrekkers in die binneland' in F. Pretorius (red.), Geskiedenis van Suid-Afrika van voortye tot vandag, bl. 130-150. Tafelberg, Kaapstad.

Zuid-Afrikaansch Republiek, s.a., Debatte in die Volksraad, deel 74-76:10435-10438, Staatsdrukker, Pretoria. 